remarks (some of which are not too easy for the non-American to understand), and it is not the least commendable point of the book that Dr. Hoffmann, perhaps because he is a mathematician rather than a physicist, is not deterred by professional solemnity from making it elear beyond any doubt that "physics is fun', a truth well known but too rarely expressed.

G. WYLLTE

\section{BRITISH DIVING BIRDS}

Haunts of British Divers

By Niall Rankin. Pp. $96+83$ plates. (London : Wm. Collins, Sons and Co., Ltd., 1947.) 12s. $6 d$. net.

T HE series of beautiful books which are being issued under the title of "The New Naturalist" receives a most welcome addition in the present volume, devoted to the account of three birds, the great crested grebe, the black-throated diver, and the red-throated diver.

Colonel Rankin, who owns the famous sanctuary on the Isles of Treshnish in the Hebrides, is not only a keen naturalist but also a first-class photographer. The result is a graphic picture of one of England's most attractive water-fowl, and two of Scotland's lesser known birds in the Highlands and Hebrides, accompanied by striking views of the romantic country in which they occur.

The account of the great crested grebe occupies the first half of the book, and is based on observations on a favourite home of these birds, a large tree-fringed lake in Kent, where eight or nine pairs regularly breed and many spend the whole year without migrating. The breeding and nesting habits are described in detail. Special mention should be made of the striking series of photographs showing the feeding of the chicks, and in particular the peculiar habit of each parent of plucking feathers from its own breast and feeding them to its offspring.

The black-throated diver does not breed south of north Perthshire and Argyll, but becomes commoner to the north, although it is not known to nest in the Orkneys and Shetlands. A remote loch in Sutherland provided the material for this study, based on a single pair of these handsome birds. The red-throated diver, a circumpolar species, has a more northerly distribution, and is comparatively common in the Orkneys and Shetlands. The author selected the island of Unst, to the extreme north of the Shetlands, for the study of this species, and also took the opportunity of making observations and illustrations of the sea-birds so abundant in that area. The curious breeding behaviour of the red-throated diver, including the position created when the duty-bird on a nest was approached by three other divers, ineluding the 'other half' belonging to this nest, presents an interesting problem in animal psychology.

The author, in his introduction, modestly states that he offers nothing new to ornithology. Whatever the truth of this statement, he offers the reader the personal observations of a keen observer accompanied by excellent photographs, which constitute a valuable addition to our knowledge of bird behaviour, and will be welcomed by all naturalists.

In addition to the eighty-four photographs by the author, special mention should be made of the coloured frontispiece and eleven pen-and-ink drawings by Margaret Myddelton.

\section{A NATURALIST'S NOTES}

\section{Highland Naturalist Again}

A Gamekeeper's Observations and Discoveries. By Dugald Macintyre. Pp. $220+8$ plates. (London : Seeley, Service and Co., Ltd., n.d.) 15s. net.

$\mathrm{D}$ UGALD MACINTYRE, during his long life spent in observing living creatures, has amassed a store of knowledge of the wild life of the Scottish Highlands equalled by few. In this, his latest book, he discourses on seal and hare, ptarmigan and capercaillie, gull and jackdaw, and a host of other creatures. $\mathrm{He}$ has a good word to say for the rook, for in spite of its misdeeds in eating grain and potatoes it is the farmer's friend in spring. Let me quote Mr. Macintyre (p. 133): "Billions of leather-jackets, which are the farmer's worst insect enemies, were taken from the fields of young oats and barley and wheat by the foraging rooks. Crops grown near the rookery grew well in bad years for 'grub', when crops too distant for the rooks to reach were destroyed almost to the last blade. There was one big farm many miles from the nearest rookery and rooks were never seen on that farm, so the crops suffered much from grub."

He describes an osprey fishing on Loch Awe in winter. 'That, surely, must be a very rare occurrence, for the osprey, when it nested in the Highlands, was a summer visitor only, and now that it nests with us no longer it is seen on spring and autumn migration, to and from its haunts in Central Europe.

Were Mr. Macintyre a less competent observer his statement (p. 166) that: "... while the loch [Loch Awe] remained wholly free from frost, but when its shallows were frozen over, the osprey was driven inland, and necessity compelled him to take other food than fish. The gamekeeper found him one day making a meal of a grouse, far inland from the loch: on another snowy day a wild-fowler of Loch Etive saw him pursue and take a wounded widgeon" would be received with at the least grave doubts, for at the season when the Loch Awe shallows freeze the osprey is normally basking in the warmth of the African sun.

On p. 162 Mr. Macintyre mentions that the Scottish capercaillie became extinct about the middle of the eighteenth century, and that the present stock is descended from birds introduced from Sweden. He makes the interesting suggestion that the birds are susceptible to disease, and that for this reason the stocks in certain districts are again decreasing fast.

The felling of great areas of Scots pine during the war years, a felling which still continues, has been injurious to the capercaillie, and the bird is also killed on all land of the Forestry Commission, on account of its habit of destroying the tender leading shoots of conifers. It would be regrettable if the caper were to die out a second time, for it is a noble bird, and adds charm to the dark miles of the old Caledonian Forest, where its cousin, the black grouse, has also become much scarcer during the last score of years.

The publishers of "Highland Naturalist Again" are to be congratulated on the printing of the book, and its excellent paper, in these days of restrictions and difficulties : there are several excellent illustrations, supplied by leading Nature photographers. 